\title{
Leaching and residual activity of imidazolinone herbicides in lowland soils
}

\author{
João Paulo Refatti ${ }^{1}$ Luis Antonio de Avila ${ }^{*}$ José Alberto Noldin ${ }^{2}$ \\ Igor Pacheco ${ }^{1}$ Rodrigo Ribeiro Pestana ${ }^{1}$
}

${ }^{1}$ Universidade Federal de Pelotas (UFPel), Pelotas, RS, Brasil. E-mail: laavilabr@gmail.com. "Corresponding author.

${ }^{2}$ Empresa de Pesquisa Agropecuária e Extensão Rural de Santa Catarina (EPAGRI), Itajaí, SC, Brasil.

\begin{abstract}
Herbicides used in the Clearfield ${ }^{\mathbb{1}}$ rice (Oryza sativa L.) production system have a potential for leaching. This can result in contamination of underground water resources and cause injury to not tolerant crops that are sown in a succession and/or crop rotation. The objective of this study was to determine the leaching potential and the residual activity of the herbicides used in the Clearfield ${ }^{\mathbb{B}}$ rice system. The experiment was conducted over a period of two years and consisted of conducting a field test to be followed by two bioassays with a year of difference between their implementation. Initially an experiment was conducted in lowland area where it was planted the cultivar of rice 'PUITA INTA CL'. Approximately one and two years thereafter, soil samples from each plot were collected at intervals of $5 \mathrm{~cm}$ to a depth of $30 \mathrm{~cm}$ (B factor) for the bioassay to evaluate persistence of herbicides. Factor $A$ was composed of mixtures formulated of imazethapyr + imazapic $\left(75+25 \mathrm{~g}\right.$ a.i. $\left.\mathrm{L}^{-1}\right)$, imazapyr + imazapic $\left(525+175 \mathrm{~g}\right.$ a.i. $\left.\mathrm{kg}^{-1}\right)$ in two doses, imazethapyr $\left(100 \mathrm{~g}\right.$ a.i. $\left.L^{-1}\right)$ and treatment control without application. Basing on results, it was concluded that the mixtures imazethapyr + imazapic, imazapyr + imazapic and imazethapyr leached into the soil, reaching depths of up to $25 \mathrm{~cm}$ in lowland soil. Imidazolinone herbicides used today in the irrigated rice Clearfield ${ }^{\mathbb{B}}$ system are persistent in soil, and their phytotoxic activity can be observed up to two years after application. Key words: imazethapyr, imazapic, imazapyr, contamination, groundwater.
\end{abstract}

Lixiviação dos herbicidas imidazolinonas em solo de várzea

RESUMO: Os herbicidas utilizados no sistema Clearfield ${ }^{\circledR}$ de produção de arroz irrigado (Oryza sativa L.) apresentam potencial de lixiviação. Isso pode causar contaminação de mananciais hídricos subterrâneos e fitotoxicidade as culturas não tolerantes semeadas em sucessão elou rotação. O objetivo deste trabalho foi determinar o potencial de lixiviação e o efeito residual dos herbicidas utilizados no sistema Clearfield ${ }^{\mathbb{}}$ de arroz irrigado. O experimento foi conduzido durante dois anos e consistiu da realização de dois bioensaio com diferença de um ano entre a implantação dos mesmos. Inicialmente foi instalado o experimento em área de várzea onde foi semeada a cultivar de arroz 'Puitá INTA CL'em área de várzea. Aproximadamente um e dois anos após, foram coletadas amostras de solo de cada parcela, em intervalos de $5 \mathrm{~cm}$ até a profundidade de $30 \mathrm{~cm}$ (fator B) para a realização do bioensaio a fim de avaliar persistência dos herbicidas. O fator A foi constituido pelas misturas formuladas imazethapyr + imazapic $\left(75+25 \mathrm{~g}\right.$ i.a. $\left.\mathrm{L}^{-1}\right)$, imazapyr + imazapic $\left(525+175 \mathrm{~g}\right.$ i.a. $\left.\mathrm{kg}^{-1}\right)$ em duas doses, imazethapyr $\left(100 \mathrm{~g}\right.$ i.a. $\left.L^{-1}\right)$ e um tratamento testemunha sem aplicação. Com os resultados obtidos, foi possível concluir que as misturas imazethapyr + imazapic, imazapyr + imazapic e imazethapyr lixiviam no solo, atingindo profundidades de até $25 \mathrm{~cm}$ em solo de várzea. Os herbicidas imidazolinonas, hoje utilizados no sistema Clearfiel ${ }^{\mathbb{B}}$ de arroz irrigado, são persistentes no solo podendo seus efeitos fitotóxicos serem observados até dois anos após sua aplicação.

Palavras-chave: imazethapyr, imazapic, imazapyr, contaminação, lençol freático.

\section{INTRODUCTION}

To meet the increased demand for food production methods has been sought aiming to increase crops productivity. Among these methods is the increasing use of pesticides that provides efficient control of weeds, pests and diseases. Herbicides, in particular, play a major role in achieving high productivity rates as it use result in reduced weed population. However, environmental contamination caused by the use of these pesticides is one of the main concerns related to current agricultural activity.

In irrigated rice cultivation, the use of herbicides with high residual activity, such as imazethapyr, imazapic and imazapyr, combined with improvements in other cultural practices, has resulted in a substantially higher production of this cereal. However, to be grown in places usually close to water sources and using large quantities of water for irrigation, irrigated rice is often cited as potentially contaminating the environment (MARCHESAN et al., 2007). These locations usually have a nearby source of water, and relief with little unevenness, thus providing ideal conditions for maintaining a film of water on the surface during part of the growing cycle. The permanence of a water blade is recommended for irrigated rice (SOSBAI, 2014), as it appears to be a physical barrier to the emergence of weeds, thus reducing competition with culture. Moreover, high satura- 
tion of the soil with water causes chemical and biological changes that result in increased availability of some nutrients (HERNANDEZ \& MEURER, 2000; SILVA et al., 2003) and herbicides (AVILA et al., 2005) present in the soil.

Paddy growing areas have the particularity to contain the level of the water table near the surface, which increases the risk of contamination of water sources. This contamination may occur through processes such as leaching and runoff. Among the herbicide transport processes, leaching stands at the forefront, which refers to the vertical movement of the product along the soil profile. The movement of herbicides in soil depends on factors related to soil, environment and physicochemical characteristics of the soil. Understanding these factors is of great importance to foresee the behavior of pesticides in different soils and to choose the optimum dosage, avoiding harmful effects to the environment and subsequent crops (ROSSI et al., 2005).

The soil's physical properties, such as texture (MONQUEIRO, et al., 2012; INOUE, et al., 2014) and soil porosity, and chemicals, such as $\mathrm{pH}$ (REFATTI et al., 2014) among others, may influence leaching of herbicides. In addition, characteristics of herbicides, such as their half-life are also crucial, since they are related to the persistence and degradation of these compounds in the environment. The permanence of herbicides at greater depths in the soil may increase the persistence thereof. This is mainly due to lower temperature, solar radiation and number of degrading microorganisms of the molecules of herbicides (COSTA et al., 2000; SILVER et al., 2001). This phenomenon coupled with fluctuation in the groundwater level increases the risk of contamination in lowland areas.

The imidazolinone group of herbicides in rice crops may have high persistence when in paddy soils. Residual activity of these herbicides in the soil may manifest itself in subsequent crops in the form of phytotoxicity (KRAEMER et al., 2009), decrease in height (PINTO et al., 2009) and plant death. Allied to this, the increase in the dose of these herbicides promoted by the use of rice cultivars with higher levels of tolerance can exacerbate the problem of residual soil.

In this context, the study of residual herbicides behavior in soil, such as leaching, is important, as it is necessary to analyze the possible adverse effects that may occur due to their utilization. A hypothesis of this study is that herbicides used in the irrigated rice Clearfield ${ }^{\circledR}$ system, leach and cause phytotoxicity up to two years after its application. The objective of this study was to determine the leaching potential and persistence of herbicides used in rice Clearfield ${ }^{\circledR}$ system.

\section{MATERIALS AND METHODS}

The experiment was conducted during the agricultural years 2010/2011 and 2011/2012, and each year there were two steps.

\section{Year I (2010/2011)}

Initially it was installed as an experiment in a lowland area. The soil in this location is classified as Hydromophic Eutrophic solodic Planosol with Francosilty texture. The design was a randomized block design with four replications, totaling 24 experimental units. It was sown with rice cultivar 'PUITA INTA CL' at a density of $100 \mathrm{~kg} \mathrm{ha}^{-1}$. When the plants were at the V3-V4 stage (COUNCE et al., 2000), herbicide treatments were applied. The treatments were imazethapyr + imazapic $\left(75+25 \mathrm{~g}\right.$ a.i. $\mathrm{L}^{-1}$, respectively) at doses of $0.75 \mathrm{~L} \mathrm{ha}^{-1}$ (imazethapyr + imazapic $1 \mathrm{X}$ ) and $1.5 \mathrm{~L} \mathrm{ha}^{-1}$ (imazethapyr + imazapic $2 X)$ imazapic + imazapyr $\left(525+175 \mathrm{~g}\right.$ a.i. $\mathrm{kg}^{-1}$, respectively), at doses of $0.1 \mathrm{~g} \mathrm{ha}^{-1}$ (imazapic + imazapyr $1 \mathrm{X}$ ) and $0.2 \mathrm{~g} \mathrm{ha}^{-1}$ (imazapic + imazapyr 2X), at the dose of imazethapyr $100 \mathrm{~g}$ a.i. $\mathrm{L}^{-1}$ (imazethapyr), and a control treatment without herbicide. The spray volume used was $200 \mathrm{~L} \mathrm{ha}^{-1}$. Other cultural practices were performed according to the techniques of research recommendations for irrigated rice in southern Brazil (SOSBAI, 2010). After harvest, ryegrass was sown in succession to rice during the autumn-winter for ground cover.

The second stage consisted of performing a bioassay in a greenhouse. For this, with the use of an extractor, soil was collected from different depths $(0-5,5-10,10-15,15-20,20-25$ and $25-30 \mathrm{~cm})$ in each section where treatments were applied in the field in the previous year (360 days). Soil coming from different layers was crushed, sieved and allocated in plastic pots at $400 \mathrm{~g}$ of soil each. Then were deposited five rice seeds of the cultivar 'IRGA 417', not tolerant to the active ingredient of herbicides evaluated. After 15 days of emergence, a waterslide three centimeters high was established, and was maintained until the end of the experiment.

Variables analyzed in the bioassay were: toxicity of herbicides to rice plants and height at 21 days after emergence (DAE). Phytotoxicity was visually assessed by assigning notes of zero to $100 \%$. On this scale, zero corresponds to no symptoms of phytotoxicity, and $100 \%$ corresponds to the death of rice plants (SBCPD, 1995). Height was determined with the aid of a millimeter ruler at $21 \mathrm{DAE}$. 
Year II (2011/2012)

In the second agricultural year, the cultivate PUITA INTA CL was sown again in the same area in order to simulate the real conditions of farming. The cultural practices were similar to those adopted in the first year of cultivation. Similarly, after the harvest, ryegrass was sown in succession to rice during the autumn-winter for ground cover. These steps were carried out without performing any evaluations. In the last step, after about two years (722 days) of applying herbicides, the second bioassay was performed in order to evaluate the potential for leaching and persistence in soil. The bioassay was conducted in the same manner as the first experiment.

Data were analyzed for normality by the Shapiro-Wilk test, and the homoscedasticity by Levene test. They were then subjected to analysis of variance $(\mathrm{P} \leq 0.05)$ and the means were compared by Tukey test $(\mathrm{P} \leq 0.05)$ and confidence intervals $(95 \%)$.

\section{RESULTS AND DISCUSSION}

All data analyzed met the assumptions of the mathematical model. There was a significant interaction between the soil layers and herbicides used in all evaluations, suggesting that the herbicides studied differ in mobility throughout the soil profile.

In the first year, the highest phytotoxicity levels were observed in the $0-5$ and $5-10 \mathrm{~cm}$ (Figure 1A). These data differ from those reported by MARTINI et al. (2011), where by evaluating the leaching of the formulated mixture of imazethapyr + imazapic in different irrigation management, they reported a higher concentration of the herbicide in the $5-10 \mathrm{~cm}$ layer. This difference may be related to poor drainage of postharvest area associated with the presence of ryegrass grown in succession to rice during the autumn-winter for ground cover.

Occurrence of green ryegrass matter produces a microclimate at the soil surface preventing the incidence of radiation and keeps the soil moist. This condition decreases the activity of aerobic microorganisms, the main degradation mechanism of imidazolinones on the ground (FLINT \& WITT, 1997). In addition, the high incidence of rain in the off-season may have decreased the degradation of herbicides. Two treatments with the mixture imazethapyr + imazapic showed less phytotoxicity in the two upper layers. Already, treatments with imazapyr + imazapic and imazethapyr mixtures showed the highest phytotoxicity. These data indicated that the phytotoxic effects caused by residues of imazapyr + imazapic and imazethapyr are larger in relation to the mixture imazethapyr + imazapic after a year of its application.

At 21 DAE, the highest levels of phytotoxicity in layer $15-20 \mathrm{~cm}$ were observed for imazapic + imazapyr 1X and IMAZETH treatments. These data corroborated those obtained by KRAEMER et al. (2009), who reported imazethapyr at a depth of $20 \mathrm{~cm}$. BUNDT et al. (2014) observed imidazolinones leaching at depths up to $40 \mathrm{~cm}$. Toxic effects on bioindicator rice plants were not observed in the last evaluated soil layer, and for the imazethapyr + imazapic $1 \mathrm{X}$ treatment, phytotoxic effects at the layer of $15-20 \mathrm{~cm}$ were observed.

Results obtained with the plant height present similar results to those reported for phytotoxicity (Figure 1C) in the first year after the application of herbicides. For all herbicide treatments, variations in height in relation to the control were detected in the layer of $25-30 \mathrm{~cm}$. However, they did not differ from a slightly higher layer $(20-25 \mathrm{~cm})$. These variations in the lower layers may not have been caused by the action of herbicides, but by reason of the measuring scale used. These results corroborated those obtained by KRAEMER et al. (2009) who observed a decrease in the treated plants' height.

In the second year after the application of herbicides, the toxicity of the bioindicator plants was observed up to the layer of $10-15 \mathrm{~cm}$ deep, for treatments imazapyr + imazapic $2 \mathrm{X}$ and imazethapyr (Figure 1B). For other treatments phytotoxic effects to a depth of $5-10 \mathrm{~cm}$ were observed. According to the literature, higher concentration of herbicide in the intermediate layers where they are slightly degraded due to unfavorable conditions such as lower temperatures and fewer degrading microorganisms (LOUX et al., 1989; FLINT \& WITT, 1997), was expected. This result may be related to the climatic conditions caused by a lower volume of rain and higher temperature during the second year of the experiment in the field. Especially under conditions of high evaporation (FIRMINO et al., 2008), capillary movement of water moving upwardly the imidazolinone herbicides in soil (BUNDT et al., 2013), which keeps the herbicide near the soil surface in periods of rain shortage may occur. Herbicides that were once in the upper layers, are subject to further degradation by the decomposing microorganisms. This may have been responsible for lower phytotoxicity indices reported in the second year of evaluation.

Regarding the height of plant, of the second year (Figure 1D), results showed similarity with the phytotoxicity of the same year of assessment except in the $0-5 \mathrm{~cm}$ layer of imazethapyr + imazapic treatment 


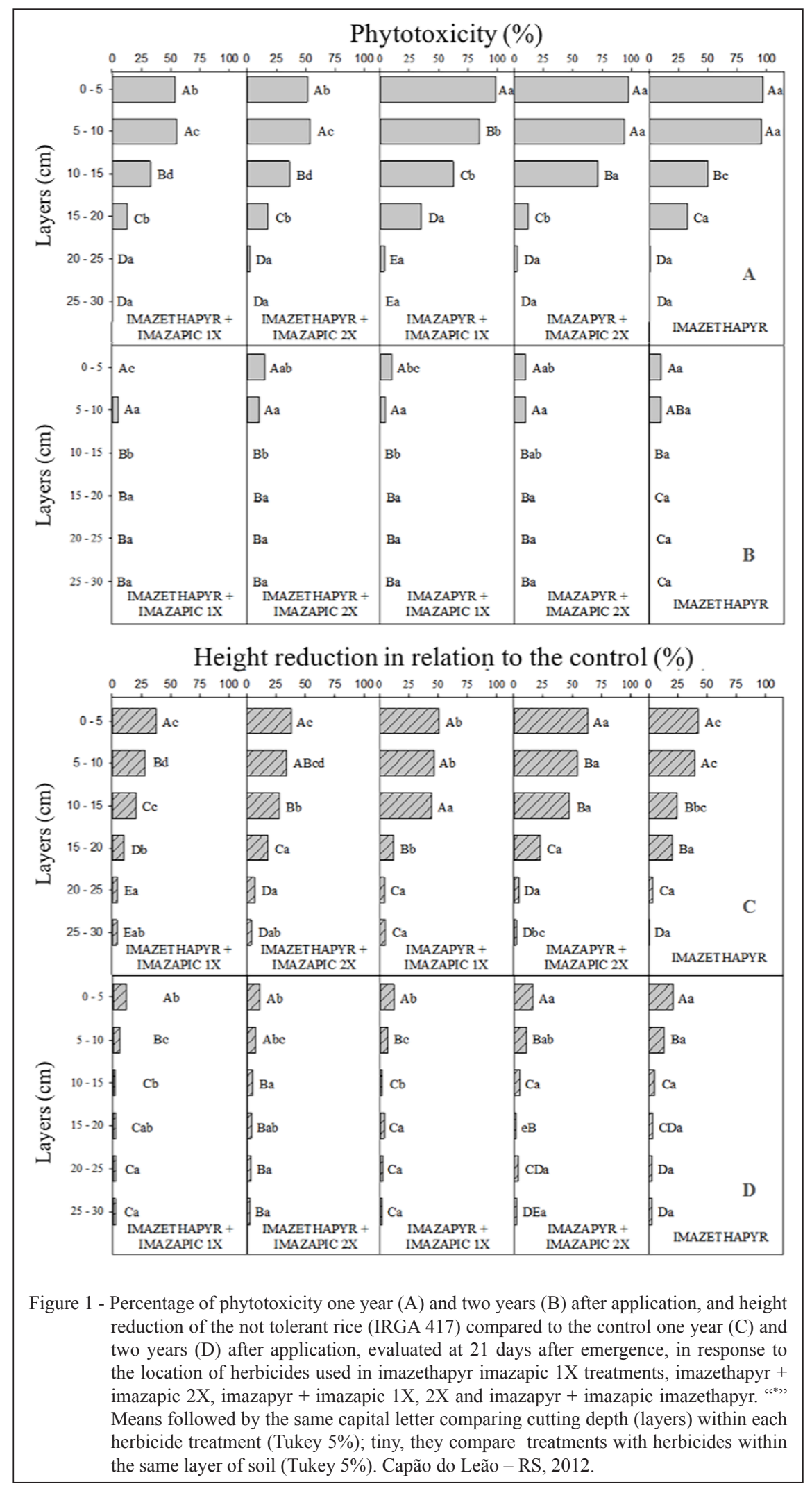

Ciência Rural, v.47, n.5, 2017. 
1X which was not observed phytotoxicity, but detected a small reduction in height compared to the control.

However, this study helps in understanding the environmental behavior of the group imidazolinone herbicides commonly used in major crops such as rice and soybean. It is worth noting that, to be related to several factors, edaphoclimatic, behavior of these herbicides may present differently in each place where they are applied. Thus, the analysis of each particular situation of the area where they will be applied is of great importance in order to reduce the probability of contamination of underground water reserves in addition to causing subsequent crop damage (ALISTER \& KOGAN, 2005).

Values of plant reduced height, obtained in the second year of this experiment may, at first, seem low and unlikely to cause reduction in final grain yield. However, the continued use of these herbicides can lead to increased concentration of the same in the soil causing serious environmental problems and human health.

\section{CONCLUSION}

The mixtures imazethapyr + imazapic, imazapyr + imazapic and imazethapyr leach into the soil, reaching depths of up to $25 \mathrm{~cm}$ in lowland soil. Imidazolinone herbicides used today in the irrigated rice Clearfield ${ }^{\circledR}$ system are persistent in soil, and their phytotoxic effects can be observed up to two years after application.

\section{ACKNOWLEDGEMENTS}

To the Universidade Federal de Pelotas (UFPel) for the availability of its structure and feasibility of the research carried out. To the Coordenação de Aperfeiçoamento de Pessoal de Nível Superior (CAPES) for the financial support, to the Conselho Nacional de Desenvolvimento Científico e Tecnológico (CNPq) for the productivity grant in research of the second author. To CAPES for the master's scholarship of the first author.

\section{REFERÊNCIAS}

ALISTER, C.; KOGAN, M. Efficacy of imidazolinone herbicides applied to imidazolinone-resistant maize and their carryover effect on rotational crops. Crop Protection, v.24, p.375-379, 2005. Available from: $<\mathrm{http}$ //dx.doi.org/10.1016/j.cropro.2004.09.011>. Accessed: Feb. 04, 2017. doi: 10.1016/j.cropro.2004.09.011.

AVILA, L. A. et al. Efeito da umidade do solo na sorção e disponibilidade de imazetapir em três solos. In: CONGRESSO BRASILEIRO DE ARROZ IRRIGADO, 4.; REUNIÃO DA CULTURA DO ARROZ IRRIGADO, 26., 2005, Santa Maria, RS. Anais... Santa Maria: UFSM, 2005. p.190-193.

BUNDT, A. D. C. et al. Transporte ascendente da mistura formulada de imazethapyr e imazapic em resposta à profundidade do lençol freático. Ciência Rural, v.43, p.1597-1604, 2013. Available from: $<$ http://www.scielo.br/scielo.php?script=sci_arttext\&pid=S010384782013000900010\&lng=en\&nrm=iso>. Accessed: Feb. 04, 2017.

BUNDT, A. D. C. et al. Lixiviação de imidazolinonas em resposta a diferentes manejos de irrigação em solo de cultivo de arroz irrigado. Ciência Rural, v. 44, p. 1943-1949, 2014. Available from: <http:// dx.doi.org/10.1590/0103-8478cr20131216>. Accessed: Feb. 04, 2017. doi: 10.1590/0103-8478cr20131216.

COSTA, E. A. D. et al. Avaliação de isoxaflutole aplicado isoladamente ou em mistura de tanque no nivelamento do solo para controle pré-emergente de infestantes em cana-planta. In: CONGRESSO BRASILEIRO DA CIÊNCIA DAS PLANTAS DANINHAS, 22., 2000, Foz do Iguaçu, PR. Anais... Londrina: Sociedade Brasileira da Ciência das Plantas Daninhas, 2000. p.295.

COUNCE, P. A. et al. A uniform, objective, and adaptative system for expressing rice development. Crop Science, v.40, n.2, p.436-443, 2000. Available from: <http://uarpp.uark.edu/Publications/Preharvest $\% 20$ characterizatioin/Counce $\% 20$ et $\% 20 \mathrm{al} \% 202000 \% 20 \mathrm{Crop} \% 20$ Sci.pdf $>$. Accessed: Feb. 04, 2017. doi: 10.2135/cropsci2000.402436x.

FIRMINO, L. E. et al. Movimento do herbicida imazapyr no perfil de solos tropicais. Planta Daninha, v.26, n.1, p.223-230, 2008. Available from: <http://dx.doi.org/10.1590/S0100-83582008000100023>. Accessed: Feb. 04, 2017. doi: 10.1590/S0100-83582008000100023.

FLINT, J. L.; WITT, W. W. Microbial degradation of imazaquin and imazethapyr. Weed Science, v.45, n.4, p.586-591, 1997. Available from: <www.jstor.org/stable/4045996>. Accessed: Feb. 04, 2012.

HERNANDEZ, J.; MEURER. E. J. Disponibilidade de fósforo em seis solos do Uruguai afetada pela variação temporal das condições de oxirredução. Revista Brasileira de Ciência do Solo, v.24, p.19-26, 2000. Available from: <http://dx.doi.org/10.1590/S010006832000000100003 > . Accessed: Feb. 03, 2017. doi: 10.1590/S010006832000000100003 .

INOUE, M. H. et al. Potencial de lixiviação de herbicidas utilizados na cana-de-açúcar em solos contrastantes. Bioscience Journal, v.30, p.659-665, 2014. Available from: $<$ http://repositorio.unesp.br/bitstream/ handle/11449/130333/WOS000350408000021.pdf?sequence $=1>$. Accessed: Feb. 03, 2017.

KRAEMER, A. J. et al. Lixiviação do imazethapyr em solo de várzea sob dois sistemas de manejo. Ciência Rural, v.39, n.6, p.1660-1666, 2009. Available from: <http://www.scielo.br/pdf/cr/ v39n6/a245cr1006.pdf>. Accessed: Feb. 03, 2017.

LOUX, M. M. et al. Adsorption of imazaquim and imazethapyr on soils, sediments and selected adsorbants. Weed Science, v.37, n.5, p.712-718, 1989. Available from: $<$ https://www.jstor.org/stable/4045134?seq=1\#page_ scan_tab_contents $>$. Accessed: Feb. 04, 2017.

MARCHESAN, E. et al. Rice herbicide monitoring in two brazilian rivers during the rice growing season. Scientia Agricola, v.64, n.2, p.131-137, 2007. Available from: <http://dx.doi.org/10.1590/S010390162007000200005>. Accessed: Feb. 03, 2017. doi: 10.1590/S010390162007000200005 .

MARTINI, L. F. D. et al. Lixiviação de imazethapyr + imazapic em função do manejo de irrigação do arroz. Planta Daninha, v.29, n.1, p.185-193, 2011. Available from: <http://dx.doi.org/10.1590/S010083582011000100021>. Accessed: Feb. 04, 2017. doi: 10.1590/S010083582011000100021 . 
MONQUEIRO, P. A. et al. Lixiviação de saflufenacil e residual após períodos de seca. Planta Daninha, v.30, n.2, p.415-423, 2012. Available from: <http://dx.doi.org/10.1590/S0100-83582012000200022>. Accessed: Feb. 04, 2017. doi: 10.1590/S0100-83582012000200022.

PINTO, J .J. O. et al. Atividade residual de (imazethapyr + imazapic) sobre azevém anual (Lolium multiflorum), semeado em sucessão ao arroz irrigado, sistema Clearfield ${ }^{\circledR}$. Planta Daninha, v.27, n.3, p.609-619, 2009. Available from: $<$ http://dx.doi.org/10.1590/S010083582009000300023>. Accessed: Feb. 04, 2017. doi: 10.1590/ S0100-83582009000300023.

REFATTI, J. P. et al. Efeito da calagem na lixiviação de imazethapyr e imazapyr em solo de cultivo de arroz irrigado. Ciência Rural, v.44, p.1008-1014, 2014. Available from: <http://dx.doi.org/10.1590/ S0103-84782014000600009>. Accessed: Feb. 04, 2017. doi: $10.1590 / \mathrm{S} 0103-84782014000600009$.

ROSSI, C. V. S. et al. Mobilidade do sulfentrazon em Latossolo Vermelho e em Chernossolo. Planta Daninha, v.23, n.4, p.701-
710, 2005. Available from: <http://dx.doi.org/10.1590/S010083582005000400019>. Accessed: Feb. 04, 2017. doi: 10.1590/ S0100-83582005000400019.

SILVA, L. S. da et al. Alterações nos teores de nutrientes em dois solos alagados, com e sem plantas de arroz. Ciência Rural, v.33, n.3, p.487-490, 2003. Available from: <http://www.scielo.br/pdf/ cr/v33n3/a14v33n3.pdf>. Accessed: Feb. 03, 2017.

SOCIEDADE BRASILEIRA DA CIÊNCIA DAS PLANTAS DANINHAS (SBCPD). Procedimentos para a instalação, avaliação e análise de experimentos com herbicidas. Londrina, 1995. 42p.

SOCIEDADE SUL-BRASILEIRA DE ARROZ IRRIGADO (SOSBAI). Arroz irrigado: recomendações técnicas da pesquisa para o Sul do Brasil. Porto Alegre, 2014. 192p.

SOSBAI (SOCIEDADE SUL-BRASILEIRA DE ARROZ IRRIGADO). Arroz irrigado: recomendações técnicas da pesquisa para o Sul do Brasil. Porto Alegre: Pallotti, 2010. 188p. 